\title{
The Exclusive Economic Zoner An Exciting New Frontier
}

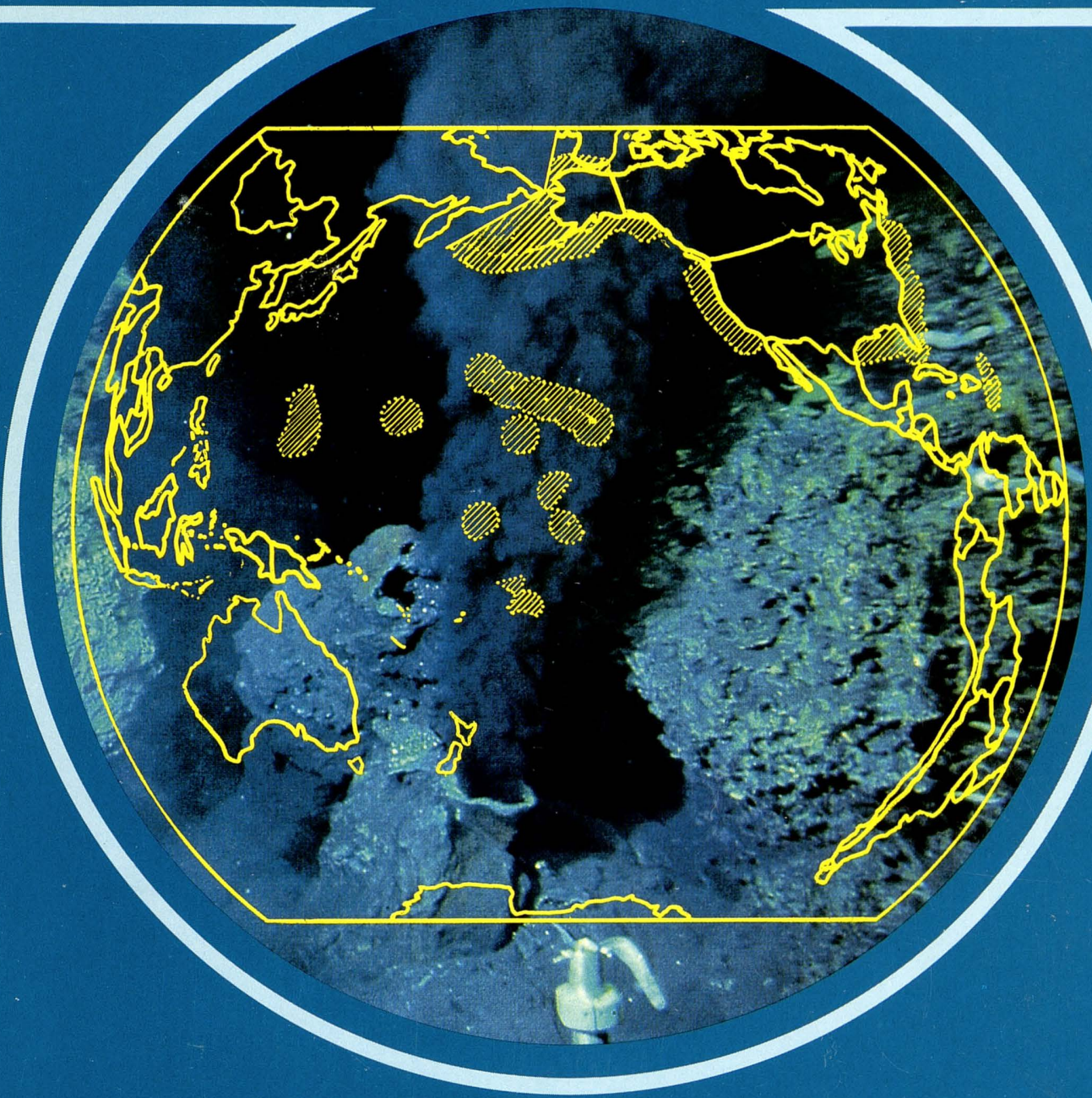




\section{The Exclusive Economic Zone: An Exciting New Frontier}

by

Bonnie A. McGregor

and Terry W. Offield

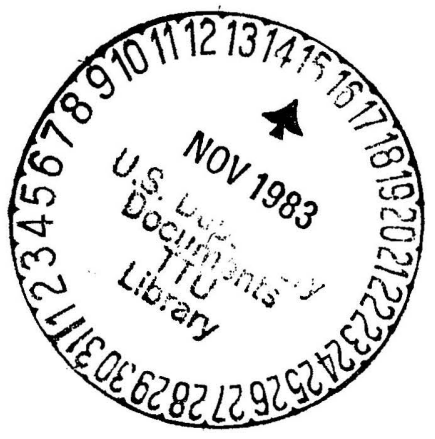

Urited States Department of the Interior JAMES G. WATT, Secretary

\section{Geological Survey}

DALLAS L. PECK, Director
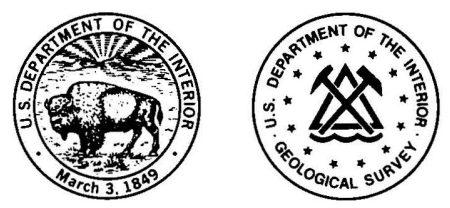

ON THE COVER: Map of the Exclusive Economic Zone superimposed on a photograph of a mineral-laden plume of hot water, discharging from the sea floor (Photo courtesy of William R. Normark). 


\section{The}

\section{Exclusive}

\section{Economic}

\section{Zone}

On March 10, 1983, President Reagan proclaimed that the ocean area from a line 3 miles off the coast of the United States and its island territories out to 200 nautical miles (see center spread) was the Exclusive Economic Zone (EEZ) of this Nation. This action gives our Nation jurisdiction over the vast living and nonliving resources within those 3.9 billion acres. The importance of the EEZ is emphasized when its size is compared to the total onshore area of the United States and its territories of only 2.3 billion acres. This new area may well be analogous to the Louisiana Purchase of 1803 , which doubled the area of our country by extending its border west to the Rocky Mountains. Just as the Lewis and Clark Expedition (1804-1806) was mounted in order to learn about the land and resources of this vast new territory, the Presidential proclamation of the EEZ provides our Nation with an enormous new frontier for investigation. This pamphlet briefly describes the offshore geology and the seabed resource potential of the EEZ, and it provides a window to the exciting possibilities for research and exploration in this vast underwater frontier.

\section{Geology and Resources}

Geology and geologic processes do not stop at the ocean's edge. The undersea area of the EEZ includes much of our continental margin which is the edge of the continent as it extends out under the Atlantic, Pacific, and Arctic Oceans, the Gulf of Mexico, and the Caribbean and Bering Seas. Like our onshore land, this 200mile-wide zone has a diverse and fascinating geology and history. Geologists have been actively studying this area because it affords an opportunity to learn more about the processes and forces responsible for shaping our continent and controlling the distribution of its resources.

The U.S. continental margin can be divided into a series of provinces called the Continental Shelf, Continental Slope, and in many areas a Continental Rise, which occur in progressively deeper water. The complexity of studying the provinces and of developing their resources increases in deeper waters.

We can understand how the continental margin and its provinces formed by looking at the early history of the North American continent and its place on the Earth's surface. The Earth's crust is made up of gigantic plates of continental crust and oceanic crust which move slowly (a few centimeters each year) relative to each other. Many plates have been created and destroyed throughout geologic time. Most continental plates extend far out under the covering 
ocean and ultimately give way to a neighboring plate of oceanic crust or (in areas of narrow seas) to an adjacent continental plate. According to the plate-tectonic theory, over hundreds of millions of years the crustal plates occasionally are broken along rift zones, and the huge fragments then spread away from the rift as though borne on conveyor belts in the Earth's underlying mantle. As these fragments move, the leading edge sooner or later collides with another plate. Depending on the kinds of plates and the nature of their collisions, this process may build a mountain range (such as the Rocky Mountains) or an oceanic island arc (such as the Mariana

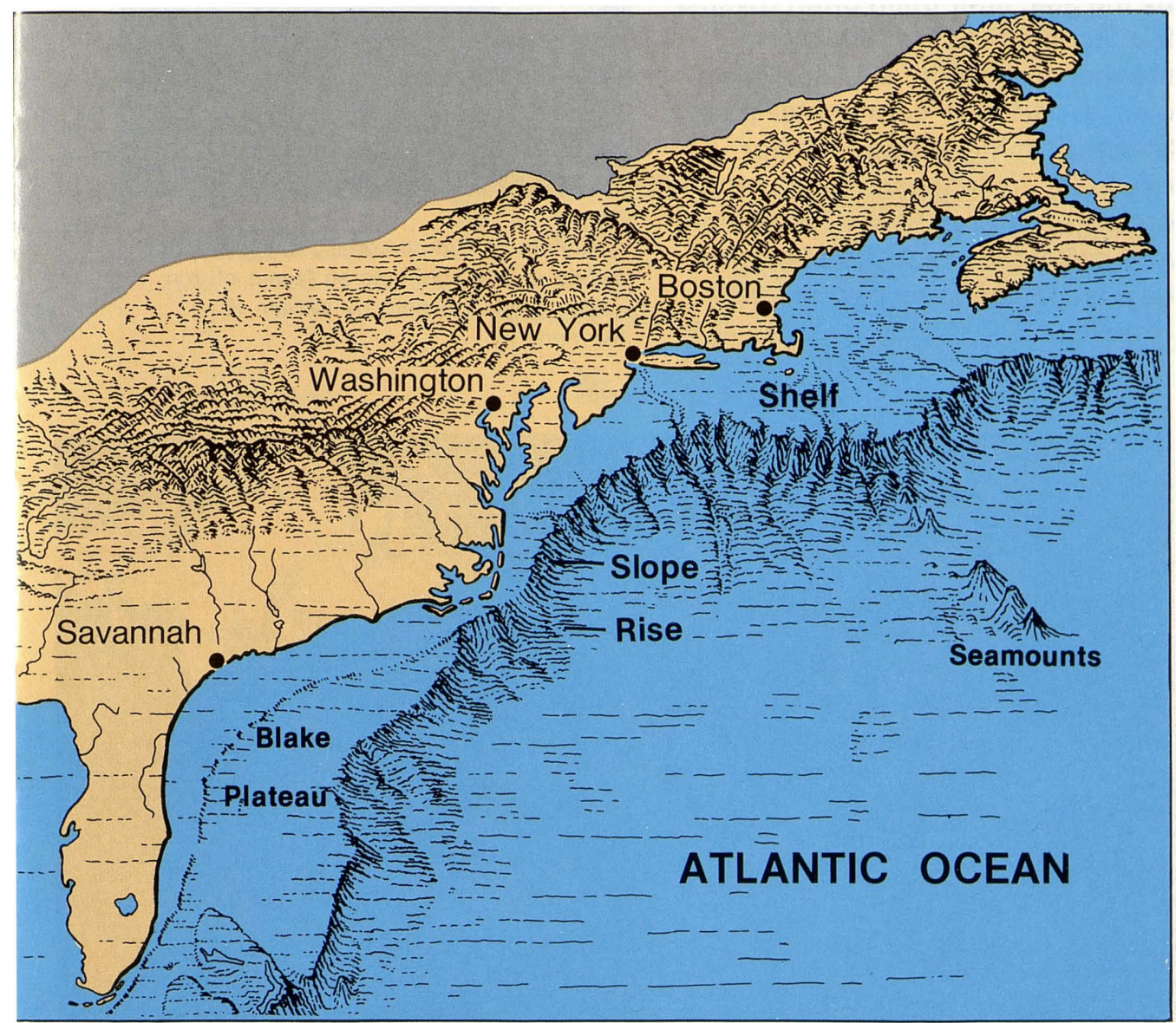

The U.S. Atlantic continental margin (a trailing edge, passive type margin) is composed of a broad flat Continental Shelf, an eroded steep Continental Slope, and a gently seaward-dipping Continental Rise. Buried beneath the shelf and slope are a series of deep basins now being evaluated for their resource potential (drawing by Tau Rho Alpha). 
Islands or Aleutian Islands). The collision (or "subduction") zones and rift zones are areas of active volcanoes and earthquakes. In this process, rocks formed in the oceans, even whole marine basins, are emplaced onto continents, where erosion may expose them for study millions of years later. Broad reaches of continental crust also may subside and be invaded by the sea; later uplift often reveals the resulting record of shallow marine deposition and erosion over a part of a continental plate. Similarly, mineral deposits (for example, manganese, cobalt, and copper) forming on the ocean floor and petroleum deposits of marine basins may become part of landmasses.
Two hundred million years ago, the supercontinent called Pangea composed of North America, South America, Africa, and Europe

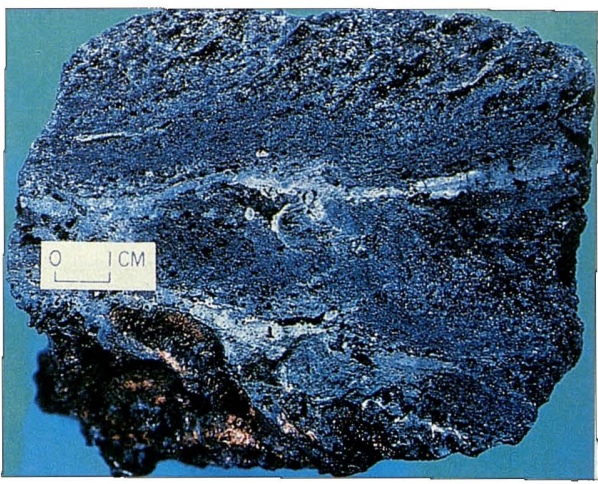

A sample of hydrothermally deposited zinc sulfide shows light colored layers of iron sulfide (pyrite) (Photo by William R. Normark).

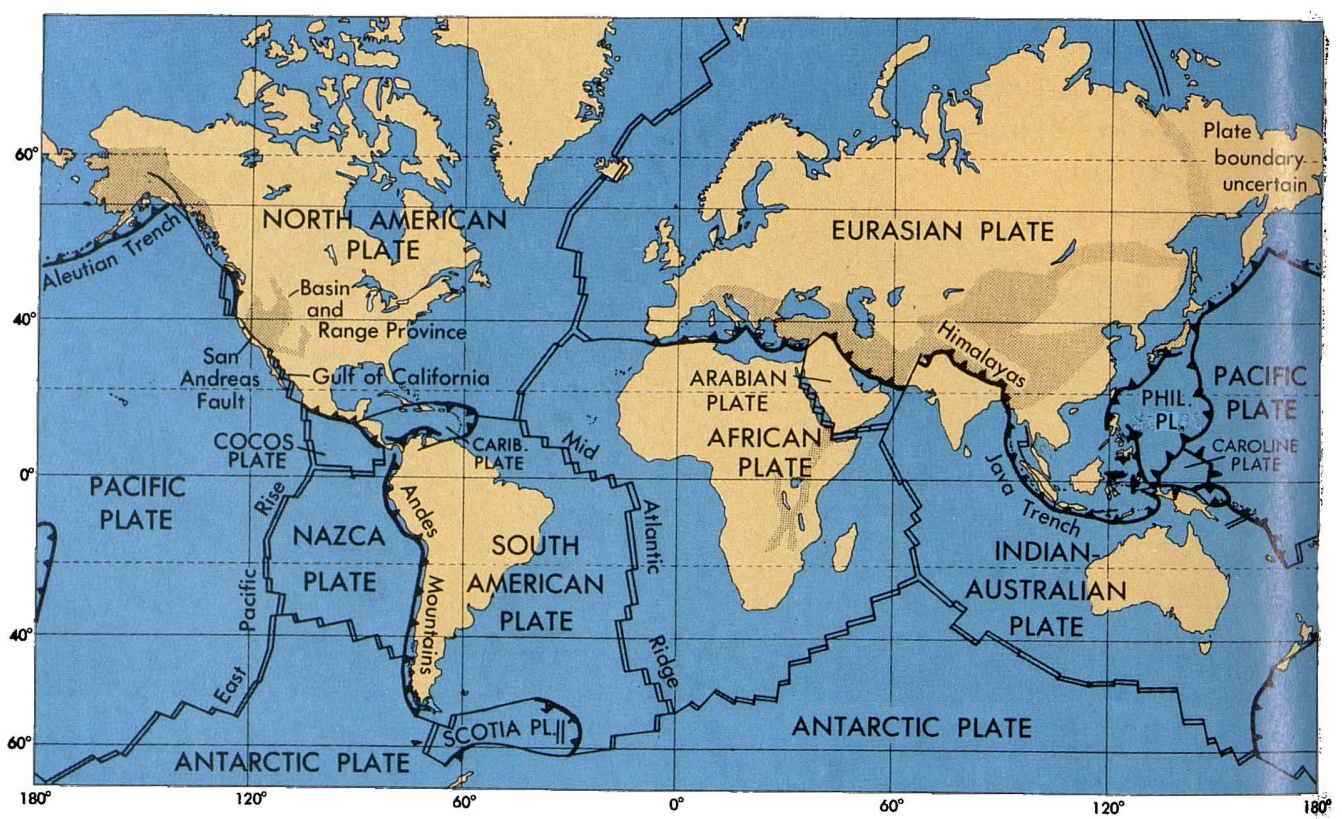

Lithosphere plates of the Earth. 
began to break up with North America moving to the west-northwest. The Pacific coast has been the leading edge of North America as it moved northwestward overriding the sea floor of the Pacific Ocean, which has produced tectonic and volcanic activity. The Pacific coast of North
America, therefore, is termed an active continental margin. The Atlantic coast is the continent's trailing edge and is called a passive margin. These different forces acting on the continental margins have made them, and hence the $E E Z$, geologically diverse, with varied histories and resources.

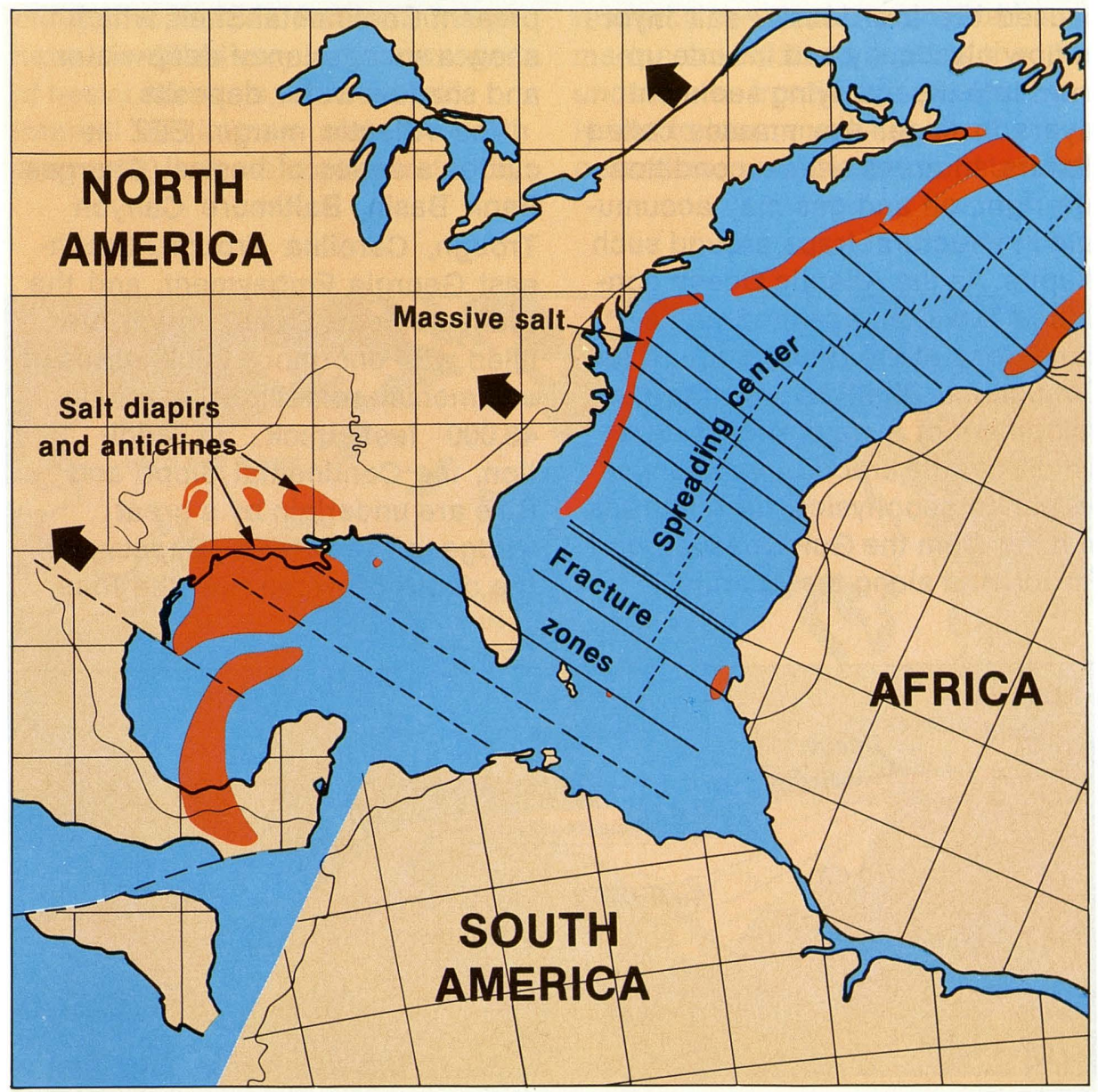

In the early stages of the development of the U.S. Atlantic continental margin, North America drifted away from Africa, Europe, and South America. Salt was deposited in this narrow, highly saline Atlantic Ocean (drawing by Kim Klitgord). 


\section{The Atlantic Margin}

As North America drifted northwest, the Atlantic Ocean began to form. In its early narrow days, the Atlantic must have been a shallow, highly saline sea with much evaporation; this process is recorded by thick layers of salt. Salt also was deposited in the Gulf of Mexico at this time. As the ocean widened, sediments poured in and were deposited on top of the salt. The weight of these sediments caused the low-density salt layer to flow plastically and intrude upward into the overlying sediment layers in finger-like masses called diapirs. In areas where conditions are right, oil and gas may accumulate in structural traps around such diapirs. As the Atlantic Ocean continued to widen, oceanographic conditions at the (then) edge of the Continental Shelf favored the development of a major reef system which can be traced, by seismicreflection geophysics, for hundreds of miles from the Gulf Coast around Florida and along the Atlantic
Coast. Such reefs also are promising structures for oil and gas deposits. Behind the reef system, sediments carried by rivers filled in a series of basins which formed during North America's breakaway from Pangea. Sea level rose and fell many times during the construction of the continental margin. These sea level changes are recorded by the rocks sampled in deep oil-test wells drilled on the present Continental Shelf, which show a succession of deep-water and shallow-water deposits.

The Atlantic margin EEZ includes a series of basins (Georges Bank Basin, Baltimore Canyon Trough, Carolina Trough, Southeast Georgia Embayment, and the Blake Plateau Basin) which are filled with enormous thicknesses of sediments, sometimes reaching 43,000 feet thick. In addition, the Continental Slope and Rise are underlain by a great wedge of sediments. Because of the depth of water over the Rise,

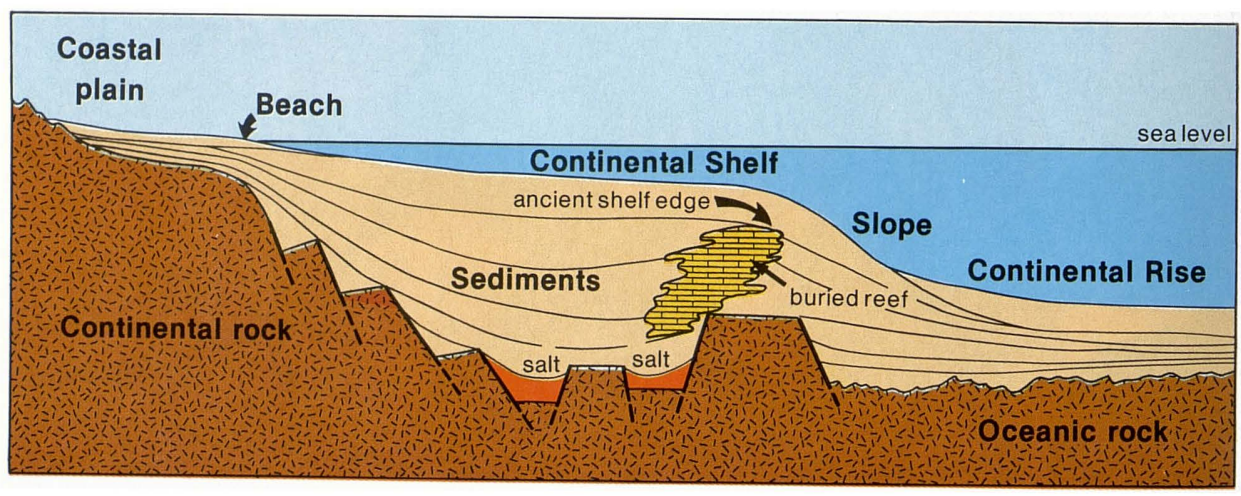

Generalized cross section of the U.S. Atlantic continental margin shows a deep basin, buried beneath the shelf and slope, which is filled with sediments. A buried reef marks an old shelf edge. The basin sediments and the reef are being evaluated for their oil and gas potential. 
this area is just beginning to be evaluated for its resource potential. The deep basins, buried reefs, and the Continental Rise are all targets for petroleum exploration, but some of them are in such deep water that exploration must wait for more favorable economic conditions.

In addition to the petroleum potential of the Atlantic margin, the EEZ has a significant potential for mineral resources. Recent surveys have identified very large tonnages of heavy minerals, of economic interest for titanium and rare-earth elements, that are concentrated by sea-floor currents in relatively shallow water on the Continental Shelf. Other surveys have shown that phosphates and pavement-like deposits of manganese cover the Blake Plateau off the Carolina coast.

In the last two or three decades, improved techniques for mapping the topography of the sea floor and for taking photograph-like sonar images plus the use of deep-diving research vessels have enabled marine scientists to explore the underwater frontier more effectively and to learn more about processes responsible for construction

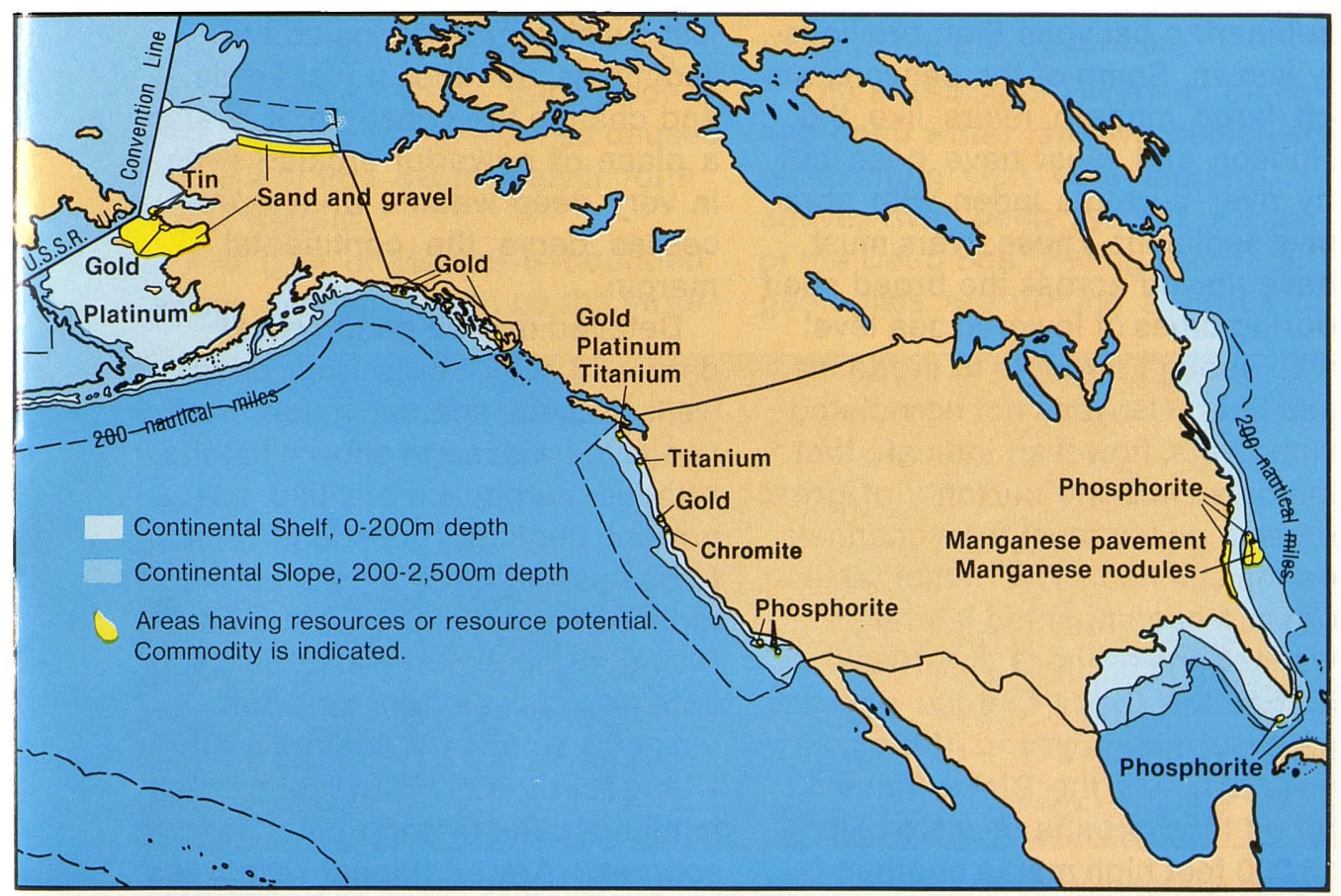

The EEZ also contains deposits of manganese, phosphorite, gold, platinum, and titanium. Many of these minerals occur in sand and gravel deposits on the Continental Shelf. 


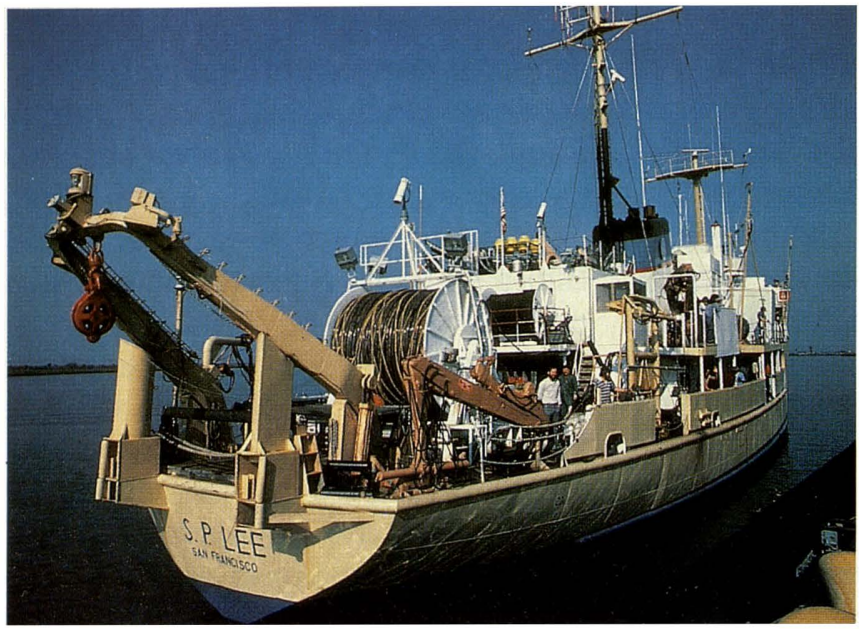

Geologists use oceanographic research ships like the USGS Research Vessel S. P. LEE to study the sea floor.

of the continental margin. Recent studies have shown that the Atlantic margin is more dissected by submarine canyons than previously known. Some of the canyons are off large modern rivers like the Hudson and must have been cut by river currents laden with abrasive sediment. These rivers must have flowed across the broad shelf during times of lowered sea level with enough strength to erode the sea floor. Canyons not associated with rivers, however, indicate that major submarine currents of great erosive power must form channels on the sea floor. This remarkable erosion accompanied lateral wanderings of the Gulf Stream across the Blake Plateau over the past few million years. At the seaward edge of the Blake Plateau, far off the Carolina coast, a cliff 13,000 feet high marks another example of marine erosion. This erosion may have a very important effect on resources within the con- tinental margin, breaching oil traps and reworking and redistributing heavy minerals. The ocean is not just a sink for the deposition of sediments, nor does it just erode and change the coastline; it is also a place of powerful erosion even in very deep waters, whose processes carve the continental margin.

Detailed marine geophysical data and rock cores from deep wells remain sparse; much work needs to be done to show what the Atlantic margin is really like. Important geologic questions remain to be answered. What is the nature of the Continental Slope and Rise? How does such powerful erosion occur on the sea floor far from land? At what rate does this erosion occur today? How has erosion influenced the distribution of resources? Are additional resources buried within the thick pile of sediments of the continental margin? 


\section{The Gulf of Mexico}

Although the EEZ in the Gulf of Mexico is also a trailing edge, passive margin, it is very different from the Atlantic margin. We have already mentioned the early history of the Gulf of Mexico, in which a thick salt layer was deposited about 170 million years ago during the Jurassic Period of geologic time. This thick, low-density salt layer is very important, because the weight of overlying sediments causes the salt to flow, deforming the sediments and shaping the morphology of the sea floor into ridges, troughs, and hills.

The Mississippi River flows into the Gulf of Mexico from the north and has deposited as a large delta a thick pile of sediment eroded from the Central United States. The weight of these thick sediments on top of the salt has caused the salt to flow extensively to form many diapirs.

The Gulf of Mexico is bounded on the east and south by the large carbonate platforms of Florida and the Yucatan Peninsula of Mexico. These platforms were constructed by marine organisms. Coral reefs now grow where the tops of ridges or hills formed by the salt are in the warm shallow water of the Gulf. Abundant organic material generated by organisms in the warm nutrient-rich water and a high rate of sedimentation have provided conditions favorable for the generation of oil and gas. The extensive distribution of diapirs also provides many traps to accumulate this oil and gas. These resources now are being actively exploited in the shallow water of the Gulf Coast. The EEZ allows drilling to be extended into deeper water to tap new reservoirs.

The Mississippi River, its delta, and deep water fan give geologists an exciting view of a modern, active, river delta system. As part of the Deep Sea Drilling Program, geologists are drilling a series of

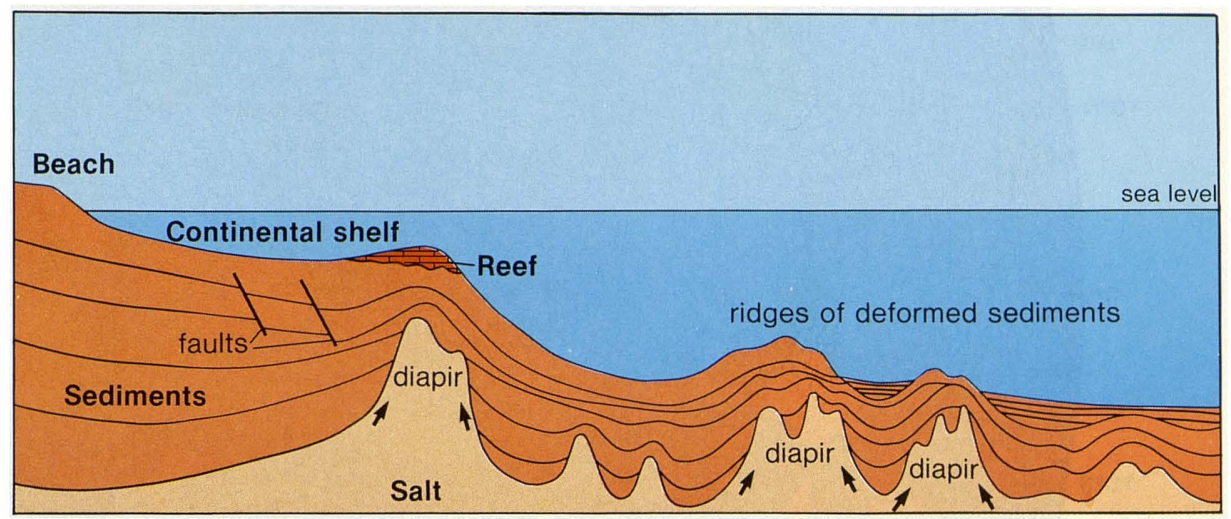

Generalized cross section shows the continental margin in the Gulf of Mexico. Although this is a trailing edge, passive margin, a buried salt layer has flowed and deformed the sediments to form ridges. The rising fingers of salt are called diapirs. These extensively distributed structures provide many traps for oil and gas accumulation. 
cores in the Mississippi Fan in September 1983 to study the processes which have formed it. On land in buried basins, oil and gas are associated with ancient river deltas and fans. Studies of the dynamic processes now active on the Mississippi River system will enable scientists to understand and more efficiently develop petroleum reservoirs of both modern and ancient deltas and fans.

The Gulf of Mexico is a dynamic area today. We need to learn more about the resource potential of its Continental Slope and Rise, and of the deep basin of the Gulf which is dominated by salt tectonics. What are the processes active on the sea floor today which shape and build a river delta and fan complex? What are the rates and magnitudes of these processes? Resource exploration and scientific under- standing must go hand-in-hand as scientists decipher the geologic history of sediments and resources buried within the passive continental margin.

The Exclusive Economic Zone (EEZ), shown in yellow, covers a vast area of the U.S. continental margin. The edge of the continent as it extends out under the ocean contains a wealth of resources.

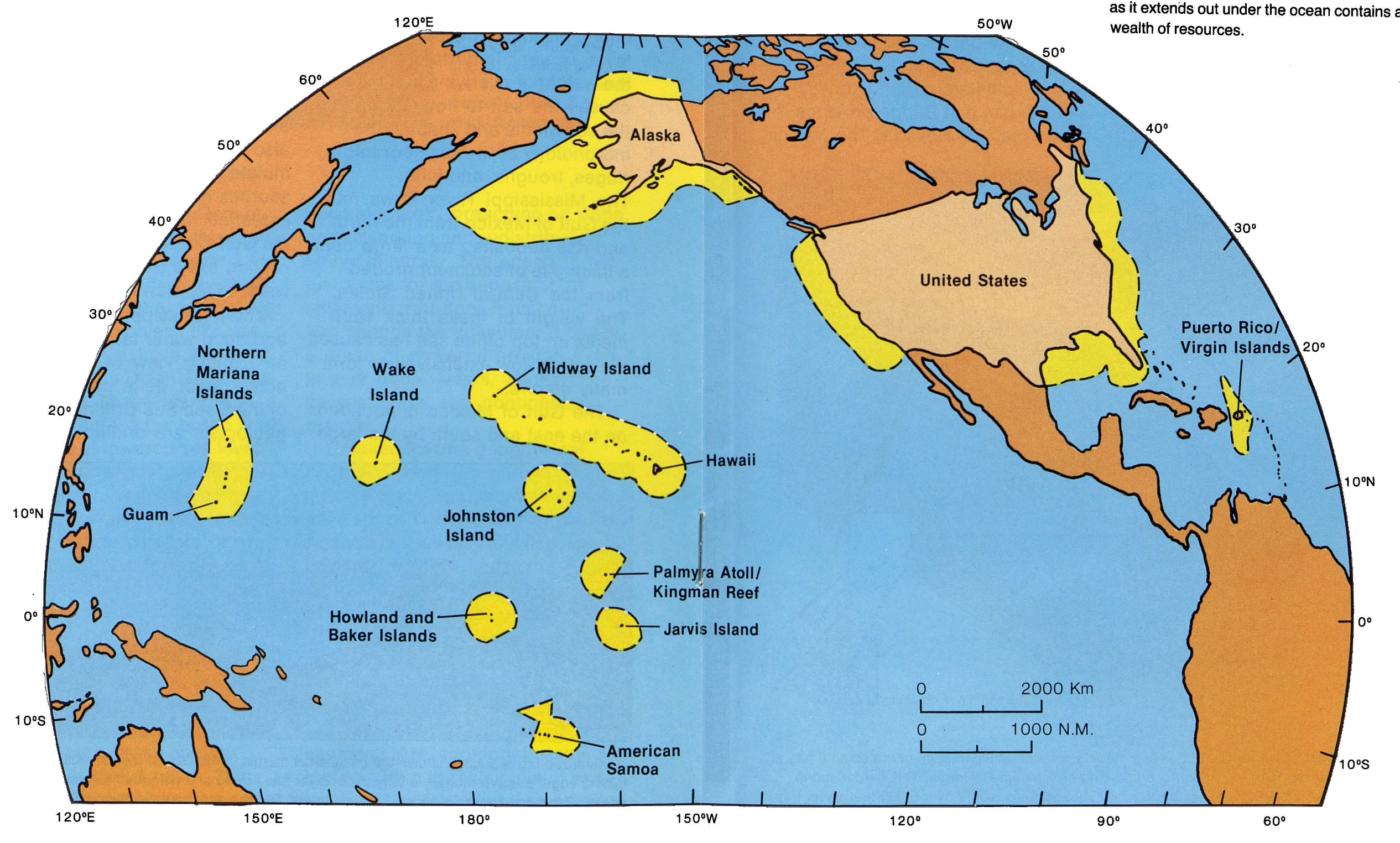




\section{The Pacific Margin}

The Pacific margin is the leading, active edge of the moving continent. Along this active margin, the continental plate of North America has collided with the sea floor of the Pacific Ocean plate. An active margin's Continental Shelf, Slope, and Rise usually are much narrower than those on a passive margin. Active margins also are marked by earthquakes associated with faulting and volcanism. The volcanic activity, such as that of Mount St. Helens, results through plate interaction with the North American plate overriding the adjacent Pacific sea floor. Cape Mendocino in California and the offshore Mendocino Fracture Zone mark the boundary of two regions along the active Pacific Coast margin. To the south, the narrow shelf is flanked seaward by a broad continental borderland composed of a number of islands, banks, and basins similar to the onshore Basin and Range province in California and Nevada. The basins

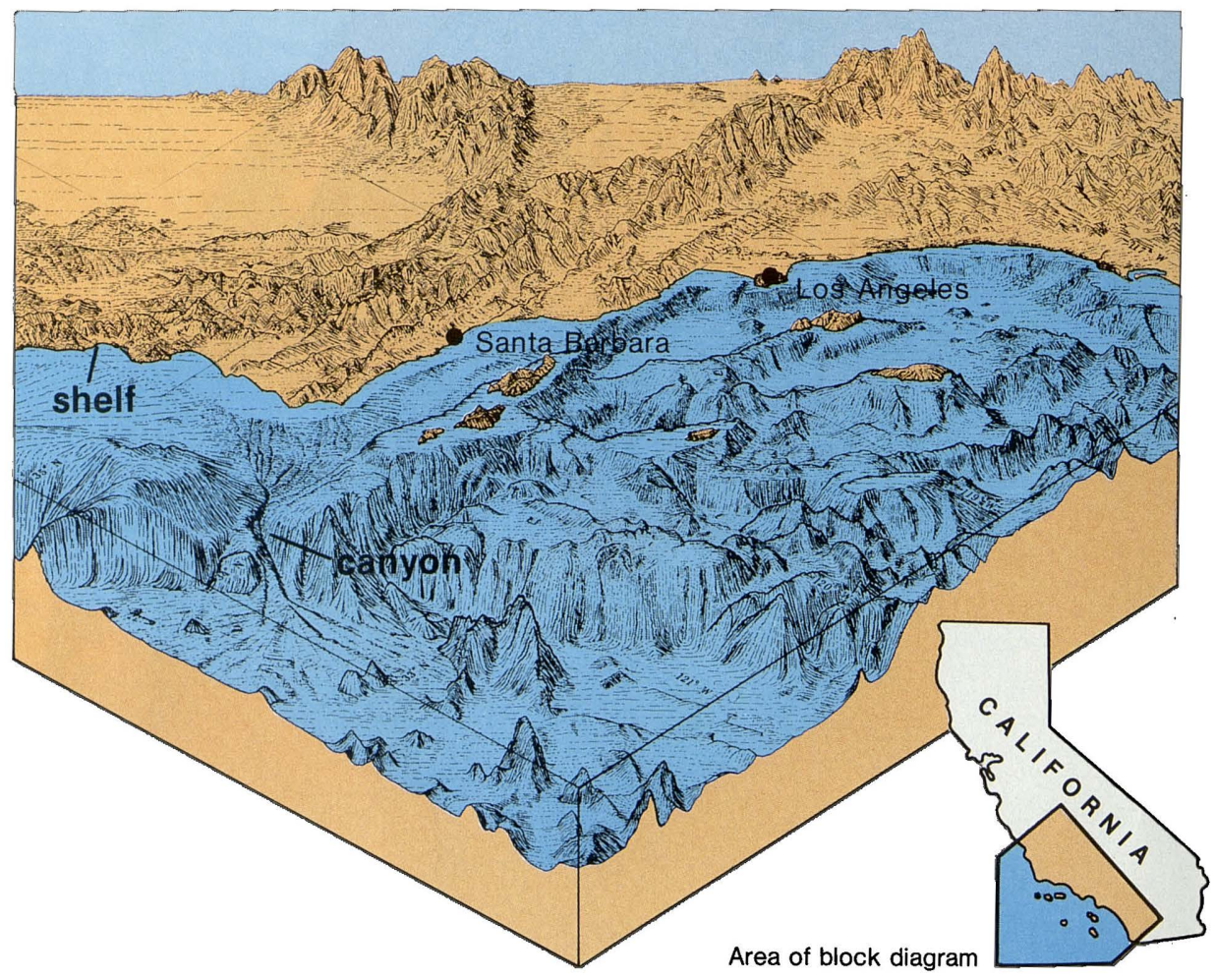

The Pacific Coast of the United States is a leading edge or active margin. In the south it has a narrow shelf flanked by the continental borderland of southern California. This borderland is composed of many banks, islands, and basins. These basins, some over 6,000 feet deep, trap sediments. Some basins close to the coast have oil reservoirs (drawing by Tau Rho Alpha). 
of the borderland are believed to have formed by tension along a fault zone of which the San Andreas fault is a part. This tension is caused by a slight change in the relative motion of the plates. These basins, some over 6,000 feet deep, provide traps which accumulate sediments transported by ocean currents or eroded from surrounding ridges. Some basins close to the Pacific Coast, such as the Santa Barbara Channel, contain old, deep-water fan deposits and are known to have oil reservoirs.

The Pacific margin, like the Atlantic, also has large submarine canyons cut into the Continental Shelf and Slope, but because of the narrowness of the Continental Shelf, the canyon heads are very close to the coast. Great quantities of sediment eroded from the adjacent land move seaward in these canyons and are deposited in deep water in large submarine fans. Monterey Canyon, which is larger than the Grand Canyon of the Colorado River, is one such canyon and fan system. In the onshore Los Angeles Basin, an ancient submarine fan now is one of the most productive oil fields. Because of this reservoir, geologists are very interested in studying the modern fans within the EEZ off the Pacific coast to learn more about their resource potential.

North of Cape Mendocino, the continental margin is very narrow. In the deep ocean off Oregon and Washington, the Gorda and Juan de Fuca Ridges are rift zones or

The Juan de Fuca and Gorda Ridges are active spreading centers off the coasts of Washington, Oregon, and northern California.

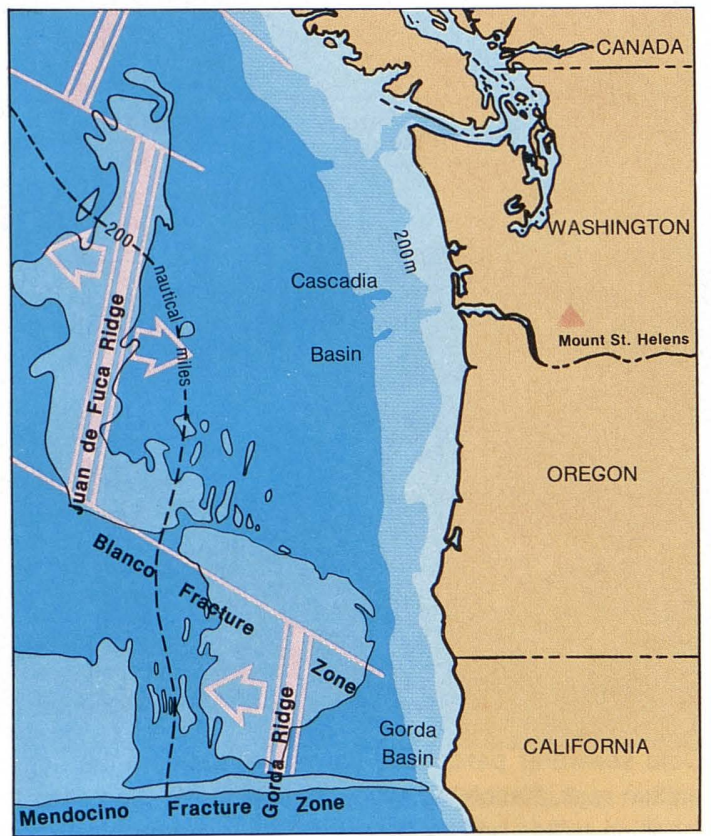




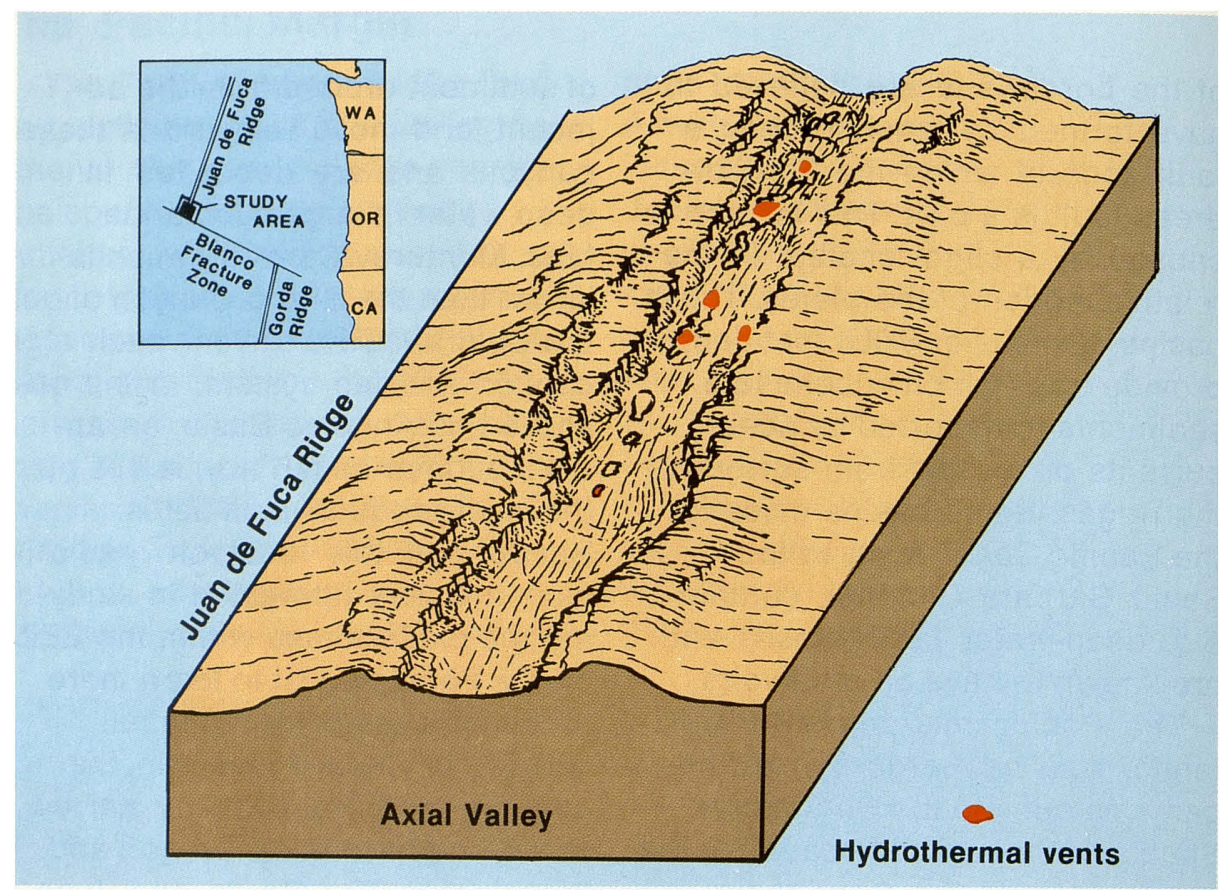

Hydrothermal vents occur along the floor of the axial valley of the actively spreading ridge crest.

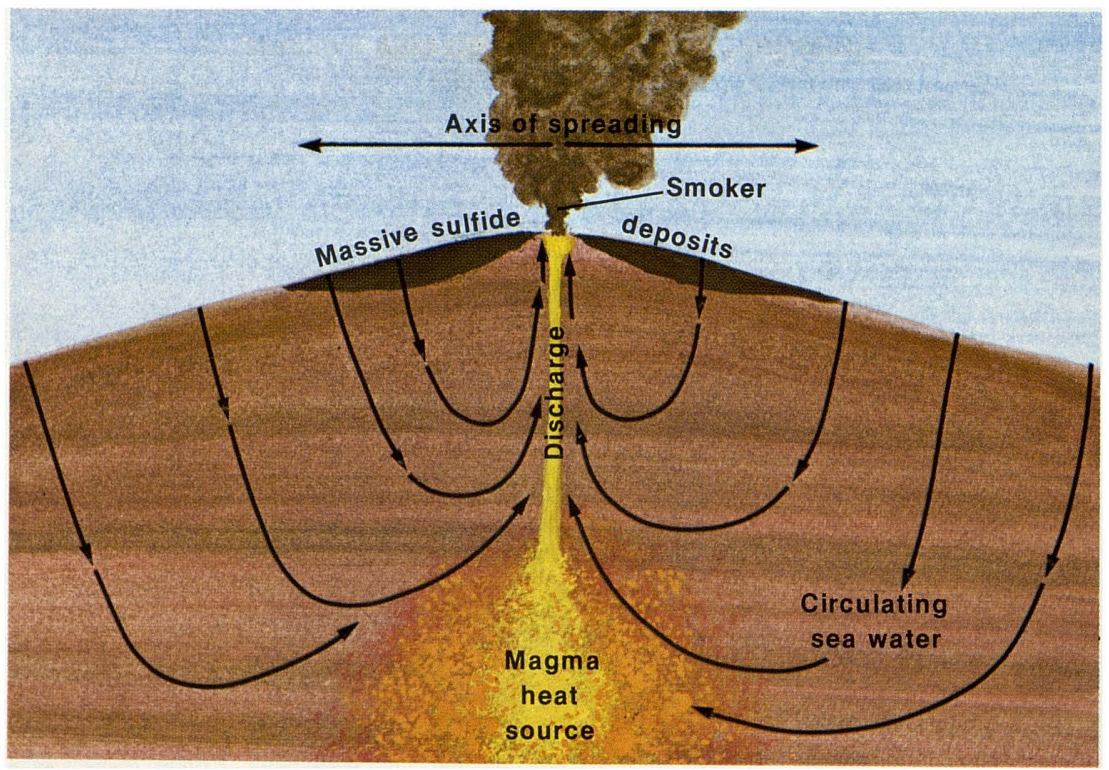

Cold seawater percolates downward beneath the ridge. The water is heated by the molten rock, dissolving many minerals, and then rises to the sea floor where it deposits massive sulfide bodies containing zinc, copper, iron, lead, cadmium, and silver. 
spreading centers along which new sea floor is being formed. In the axial valley of the rift zone, faults provide conduits by which molten rock can rise and reach the sea floor. Later, as sea-floor spreading continues, the faults also provide conduits for cold seawater to circulate downward into the hot crust. The water reacts with the hot rock, leaching from it elements such as manganese, zinc, silver, and cadmium. Warming this water sets up an active convection cell, and the mineral-laden boiling water is driven upward toward the sea floor as new cold water descends to keep the cycle going.
As pressure, temperature, and the chemistry of the solutions change, some of the minerals dissolved in the water precipitate on the walls of the fault conduit and on the sea floor. When this hot mineral-laden water reaches the sea floor, it shoots upward in a plume much like an underwater geyser. Such plumes, first discovered in 1978, are called "smokers." Most plumes are black with rich mineral content; some of them, however, have lost most of their minerals by precipitation and are white. A totally new community of marine organisms was found living in the darkness of

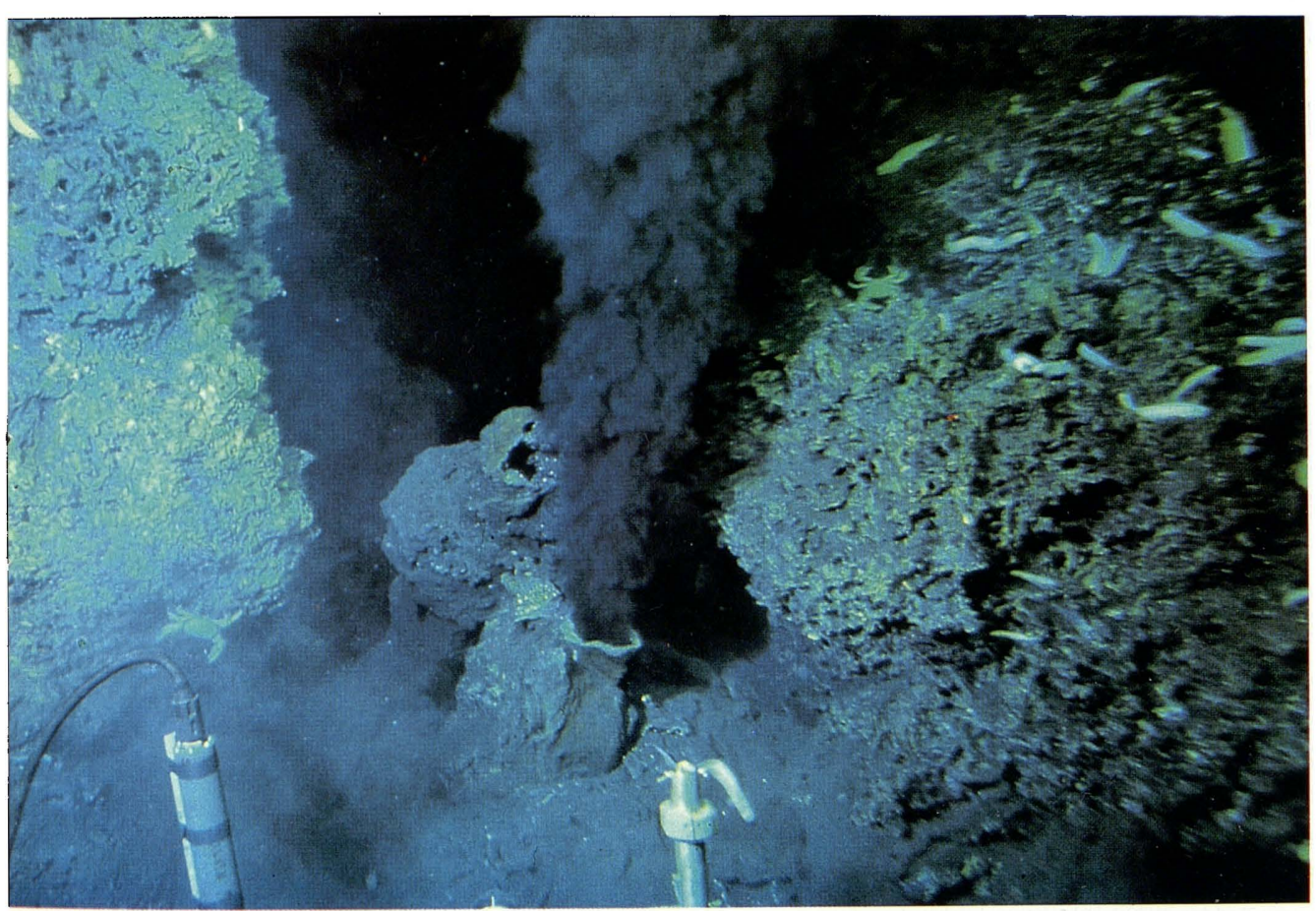

Mineral-laden hot water shoots upward in geyser-like plumes from vents on the sea floor. These mineral-laden plumes are called smokers (photo by William R. Normark). 


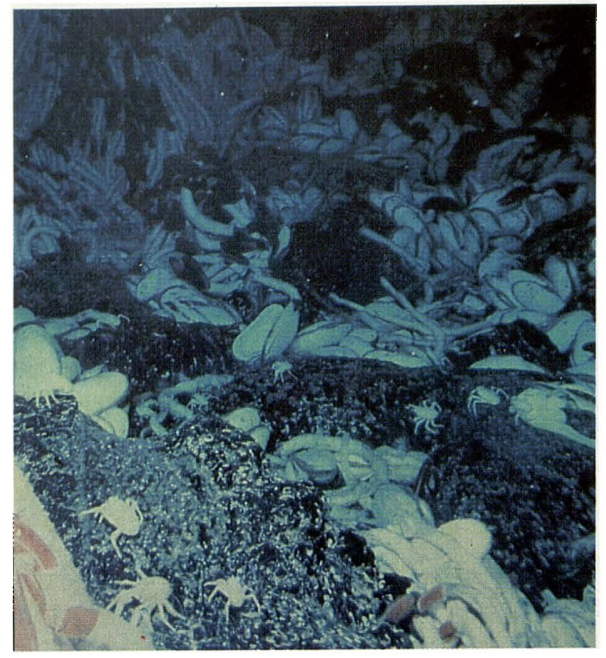

A totally new community of organisms (clams, worms, and crabs) lives in the darkness of the ridge crest and draws its nutrients and energy from the hot solutions rising from the rocks (photo by William R. Normark).

the ridge crests. These organisms draw their nutrients and energy from the hot solutions rising from the rocks, rather than from the sunlight as they would do in shallow water.

The discovery of these smokers and their mineral deposits was fascinating for geologists because for the first time they were able to watch minerals actually being deposited on the sea floor. This important discovery also provided an explanation of the probable origin and ancient geologic setting of similar deposits of massive sulfides long known and mined on land. These massive sulfides are believed to have formed at ocean spreading centers and later were plastered onto a continent by movement of the crustal plates.
The south end of the Juan de Fuca Ridge has been studied by the U.S. Geological Survey and is known to contain at least six of these sulfide-depositing, hot-water vents. The mineral deposits are unusually rich in zinc, and they also contain cadmium and silver in potentially economic quantities. If further study shows these deposits are large enough, they may be considered for future mining. Such mining will have to be highly inventive, because the deposits on the ridge crest are under nearly 8,000 feet of seawater. In the meantime, smokers are natural laboratories in which geologists can gain new understanding of how mineral deposits form.

The concept of plate tectonics is less than 2 decades old and the hydrothermal circulation that forms mineral deposits has been known for less than a decade. We have much to learn and many questions to answer. What force drives the Earth's plates and to what depth do the plates extend? How many sulfide vents and how many precipitated mineral deposits exist along the 25,000 miles of the worldwide network of ocean spreading centers? How does the mineral-forming process really work, how is it turned on and off (we know it is short-lived at any one vent), and why does it occur at one place and not another? Do mineral deposits also form at other places where volcanic heat and rising molten rock occur on the sea floor, such as at the thousands of known seamounts? 


\section{The Alaska Margin}

Alaska is a very complex patchwork of small plates, which drifted together a hundred million years or more ago. The Aleutian Islands are an arc of volcanoes flanked on the seaward side by a deep basin called a trench. Along this trench the sea floor of the Pacific Ocean is being pushed down and shoved under the continental margin. Ocean crust from over 8,000 miles away has been brought in by the plate-tectonic conveyor belt and consumed along this trench.
As this crust is pushed down deep within the earth it melts, and the molten rock (magma) then rises to form the volcanic rocks found throughout the Aleutian Islands. Minerals originally deposited within the rocks of the sea floor are also mobilized and redeposited within the island arc. Petroleum geologists also have studied island arc regions because they include deep basins with accumulations of sediments, which, if conditions are right, can contain oil and gas.

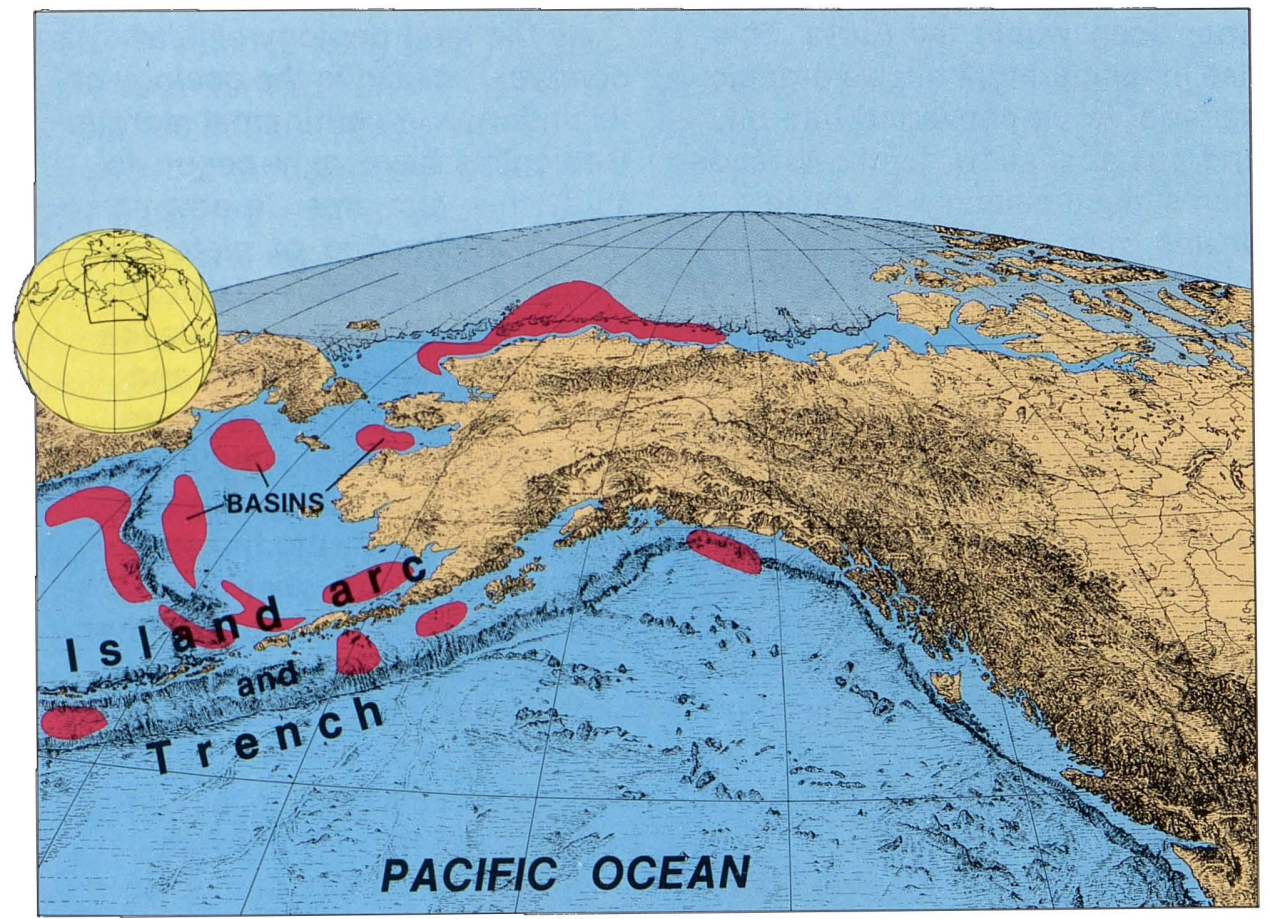

The Aleutian Islands volcanic arc is flanked on the Pacific Ocean side by a deep basin called a trench. Along this trench, the sea floor of the Pacific Ocean is shoved down under the continental margin of Alaska. Many basins with petroleum potential are associated with the island arc. The north slope of Alaska, a passive type margin in contrast to the active arc side, has a thick accumulation of sediment believed to have important petroleum reserves. Heavy mineral deposits also occur on the Continental Shelf of Alaska (drawing by Tau Rho Alpha, M. Gerin, and J. M. Joyce). 
In front of the arc, between the arc and the trench, compressional forces in the forearc basin can deform the sediments supplied by land erosion, volcanic eruptions, and organisms settling out of the water column into the basin. Cook Inlet and several other basins are near shore in this forearc region and are being evaluated for their petroleum potential. Backarc basins behind the arc are formed by tensional forces associated with the descending slab of sea floor. When the Earth's crust is pulled apart, the temperature of the rocks increases due to hot material rising from deep within the Earth. This rise in temperature allows organic material to be converted into oil and gas at shallow depth. As sediments accumulating in these basins may contain petroleum, geologists are studying a series of basins in the Bering Sea behind the Aleutian Arc.

The north coast of Alaska has thick accumulations of sediments and is a passive type margin with diapirs and other features similar to the Atlantic passive margin.

Prudhoe Bay is a giant oil field near the coast, which suggests that the continental margin, under the Continental Shelf, Slope, and Rise, also may have important petroleum reserves.

The severe climatic conditions in Alaska, especially its winter storms and ice, make it difficult for geologists to explore for resources and when found to recover them. Ice extends all the way down to the sea floor in the waters overlying the shelf, leaving large gouges in the bottom sediment. Drilling for oil under these conditions is difficult, because the ice can remove anything put on or into the sea floor.

Alaska's glaciers and rivers disgorge large quantities of sediments onto the shelf, including minerals of economic interest.

Ocean currents driven by storms can rework these sediments, concentrating and forming deposits of titanium, platinum, and gold. These deposits may be buried within the continental margin and waiting to be found.

As the land geology of Alaska is complex, so also is the geology of its underwater continental margin. Geologists have only begun to study this vast area. In advancing our understanding of plate tectonics to better understand the distribution of resources, Alaska allows us to study a trench and island arc system to learn more about the process of subduction. In the trench, what part of the sediment is plastered onto the continental margin and what part goes down the subduction zone? What is the petroleum potential of, and what are the conditions present in, the deeper parts of the forearc and backarc basins? Using our ingenuity, what technology can be developed to explore and develop the resources in the hostile climate of Alaska's northern continental margin? 


\section{Island Settings}

In addition to the continent of North America, the EEZ also includes waters adjacent to Puerto Rico and the Virgin Islands in the Caribbean, and the Hawaiian Islands, Northern Mariana Islands, and many other islands in the Pacific Ocean. Puerto Rico, the Virgin Islands, and the Northern Mariana Islands, like the Aleutian Islands, are part of an island arc. They have forearc and backarc basins, which, if conditions are right, may contain oil and gas. Cobalt-rich manganese crusts may accumulate on the exposed volcanic rocks of the arcs. Polymetallic sulfides also may be deposited underwater on the flanks of active volcanoes in the arcs.

Not all of the islands in the $\mathrm{Pa}$ cific are at the edge of a plate capping an island arc. Some, like the Hawaiian Islands, occur within the Pacific plate. They form over what geologists call a hot spot, a place where hot plumes of rock are rising from deep within the Earth. These plumes are believed to be fixed geographically; as the crustal plate of the Pacific moves over the hot spots, they form a line of volcanoes or seamounts-volcanoes that do not reach above the sea surface. The island of Hawaii is over a hot spot which causes its present volcanic activity. The trend of the chain of islands from Hawaii to Midway shows the northwest direction that the Pacific plate has moved; each island originally formed over the hot spot now under Hawaii. Although no deep basins filled with sediment are associated with this type of island, minerals accumulating on the volcano may be important. Polymetallic sulfides may be deposited by volcanic solutions or by seawater percolating through the rock as they do at the active spreading center of the Juan de Fuca Ridge. Cobalt-rich manganese crusts may be deposited on the underwater flanks of the islands and on seamounts.

Geologists have only just begun to study the geology and resources of these islands. The underwater flanks of the volcanoes can be steep and the water may be over 12,000 feet deep, which makes their study very difficult. We still need to answer the very basic questions of what are the resources and what are their distributions?

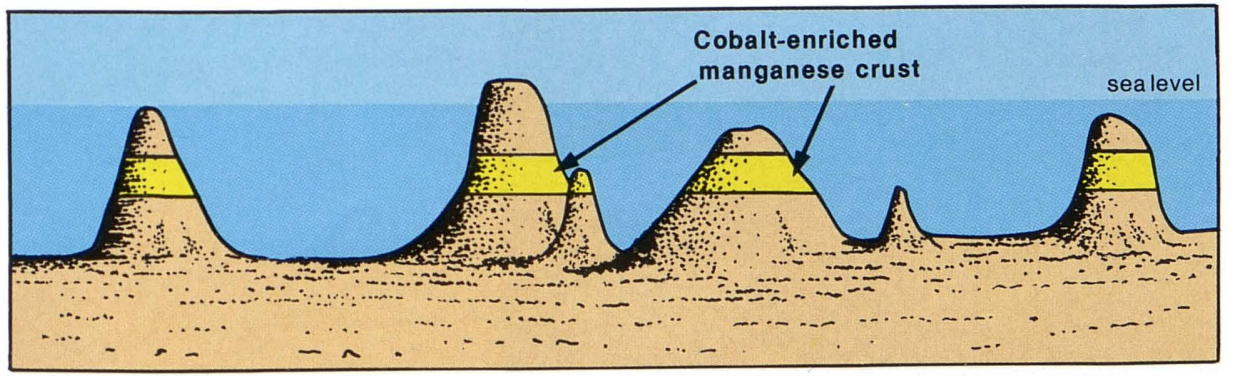

Cobalt-rich manganese crusts occur on the flanks of volcanic islands and seamounts. 


\section{Perspective}

The Earth's surface is dynamic with its moving plates, rising molten rock, and earthquakes. This concept of plate tectonics provides geologists with a means of studying the geologic evolution of the Earth and of understanding the distribution of its resources. Although three-quarters of the Earth's surface is covered by water, the edges of the continents extend far out beneath the ocean. On the continental margin sediments are deposited in basins, which, when conditions are right, can contain oil and gas. These sediments can be deformed tectonically at the edge of and within the plates by plastic flow of low density salt, or they may be sculpted by eroding ocean currents to produce the continental margin as it exists today. Ocean currents and sea water are important agents in concentrating and depositing many of our valuable minerals.

Although the ocean environment severely limits the observations a geologist can make of the seabed, it provides a laboratory for studying both modern and ancient marine sediments and mineral deposits and for observing the active processes of marine deposition and erosion. These observations can increase our understanding of the onshore geologic setting and aid in our search for economic resources. In turn, studies of former marine settings now preserved on land, together with offshore geophysical data and drillhole or surface samples, enable us to increase our geological understanding of the Continental Shelves, Slopes, and Rises, and the deep ocean floor. Major deposits of oil and gas, and important potential resources of strategic and critical mineral commodities, occur in these geologic settings.

The EEZ provides the United States with a vast new frontier to study and understand. It also gives us an immense new region with potential resources of enormous economic importance to explore and develop.

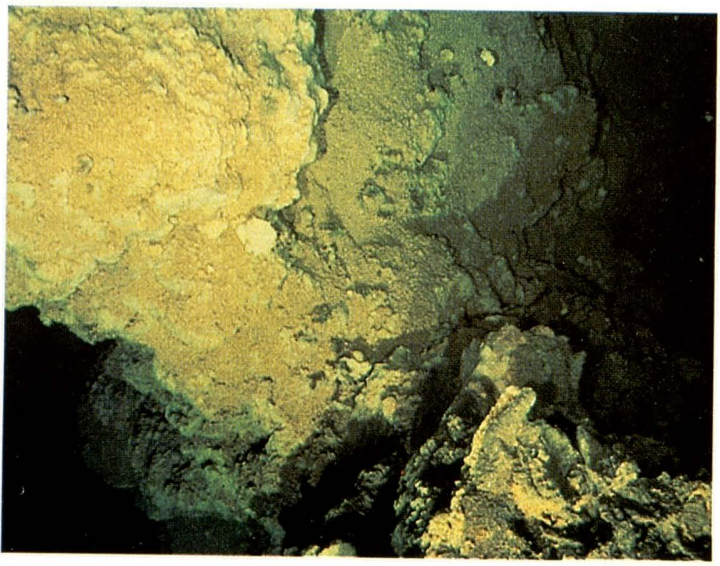

Massive suifide deposits near a mineral-laden plume on the Juan de Fuca Ridge (Photo by William R. Normark). 
As the Nation's principal conservation agency, the Department of the Interior has responsibility for most of our nationally owned public lands and natural resources. This includes fostering the wisest use of our land and water resources, protecting our fish and wildlife, preserving the environmental and cultural values of our national parks and historical places, and providing for the enjoyment of life through outdoor recreation. The Department assesses our energy and mineral resources and works to assure that their development is in the best interests of all our people. The Department also has a major responsibility for American Indian reservation (1) communities and for people who live in Island Territories under U.S. administration. 